\title{
XIII. On a metallic solution, which forms a yellow ink, that appears and disappears like that of Hellot. Read before the French National Institute
}

\section{Gillet-Laumont}

To cite this article: C. Gillet-Laumont (1802) XIII. On a metallic solution, which forms a yellow ink, that appears and disappears like that of Hellot. Read before the French National Institute, Philosophical Magazine Series 1, 14:53, 76-77, DOI: 10.1080/14786440208676164

To link to this article: http://dx.doi.org/10.1080/14786440208676164

Published online: 18 May 2009.

Submit your article to this journal $\pi$

山 Article views: 2

View related articles 
In England, Mr. Wilkinfon has employed feveral years, for fufing iron ore by coke, furnaces of lefs height than thofe which he ufed before, and he fupplies wind by three tuyeres placed at equal diftances in the circumference of the furnace.

XIII. On a metallic Solution, which forms a Yellow Ink, that appears and difappears like that of Hellot. Read before the Frencb National Infititute, by C. GirietLa umont, Aflociate*.

Some time ago, having thrown into the fire a folution of a mixture of fulphate of copper and muriate of ammonia, where it produced very agreeable colours, fome of it fell upon a piece of paper placed in the chimney, which became of a bright yellow colour. Having taken the paper from the chimney, I was much aftonifhed, fome moments after, to find that it was no longer coloured : on again expofing it to heat the colour reappeared, and difappeared in like manner on cooling.

I tried lately to repeat this experiment; and I obtained from thefe two falts, mixed nearly in equal parts, a folution of a bright yellow colour when warm, and of a beautiful emerald green when cold, which at firt gave cryftals in oblique prifms with rhomboidal bafes, and then blue cryftals in flat octaedra.

This liquor and the folution of the cryftals gave a yellow ink, which appeared yellow with heat, and difappeared with cold, but ftill better with moifture.

I obferved that thefe folutions are indebted for this property only to the muriate of copper, which when employed alone does not produce the fame effect.

On comparing this ink with that given by the muriate of cobalt, known under the name of the fympathetic ink of Hellot, it is feen that all thefe kinds of ink are indebted for the property which they have of difappearing, only to metallic muriates, which powerfully attract the moilture of furrounding bodies.

The yellow ink produced by the muriate of copper and the folutions which contain it (very different from thofe which, being at firft invifible, remain fixed after they have appeared) gives by its colour a variety very diftinct from that of Hellot, which is of a fea green: with the latter it forms varied tints of an emerald green.

- From the foumal des Mines, No. $5^{8}$. 
They may be made to appear at pleafure by the aid of heat, and to difappear very fipedily by putting the writing between the folds of paper fomewhat moift: but I muft here obferve, that it requires much care to make the experiment fucceed completely, and that a certain degree of heat mut not be exceeded; otherwife, the paper being fcorched, the writing can no longer difappear.

XIV. A fbort Viequ of the Craniognomic Syftem of Dr. GA LL, of Vienna. By L. Bojanus, M.D. Member of the Medical Societies of Jena and Paris, and of the Society of the Objerwers of Man*.

A $\mathrm{T}$ all periods, a defire to find in the exterior of man certain marks indicative of his interior faculties, his paffions, his morals, \&c., has induced the learned to eftablin fyftems of phyfiognomy more or lefs fatisfactory. The moft friking of thefe fyftems are thofe of Baptifta Porta and Lavater, the theory of the facial angle, and the fyttem of Dr. Gall.

In regard to the firft, who employed himfelf in comparing the contours of the human figure with thofe of beafts, obfervers have determined its value, and confider his principles as the fruit of a difordered imagination, as too bold, too little founded on rational obfervation, and abfolutely uncertain in its application.

The fyftem of Lavater has had more fuccefs; but while we revere the genius of that celebrated man, who was truly a great obferver, we cannot help acknowledging the inftability of the bafis on which all the opinions he advances reft; and the mind is not fatisfied with truths which can be appreciated only by an imarination equally exalted, and a touch fo delicatc as that of the author.

The theory of the facial angle, which embraces a wider field than the fyftem of Lavater, leaves us in uncertainty refpecting the detail of the faculties, and gives us only general points of view; but it prefents us with this truth, of the greateft importance-that the facial angle increafes in fize in proportion to the faculties of animals: and in this it coincides

* From the Marazin Enryclotidifer, No. 4, Meffidor, an, io. Dr. Bojanus in a note tays: "As this hifterical explanation is by no moans inrended to prove the truth of Br. Gall's Gytem, it can lcad to no decilise opinion on this fyam, which will be eftabihed by its nuthor on folid redisuing and coin rincing latimony. It is neceffary alfo (fays he) to obfcrve, that the pafteges marked sitiz incried cominas do not reti on the antwoty of Ds. Giall." 